\title{
Uji Aktivitas Antifungi Ekstrak Etanol Kulit Nanas (Ananas comosus (L.) Merr) Terhadap Pertumbuhan Pityrosporum ovale dan Candida albicans Penyebab Ketombe
}

\section{Antifungal Activity Test of Ethanol Extract of Pineapple Skin (Ananas comosus (L.) Merr) on the Growth of Pityrosporum ovale and Candida albicans Causes Dandruff}

\author{
Muhammad Yusuf ${ }^{1}$, Rugayyah Alyidrus, Wahyuni Irianti, Nurfiddin Farid \\ ${ }^{1}$ Fakultas Farmasi, Universitas Megarezky
}

$\left.{ }^{*}\right)$ yusuf.sukarta@gmail.com

\begin{abstract}
Dandruff is a scalp condition which is usually characterized by itching and flaking of the scalp, this can be caused by the fungus Pityrosporum ovale and Candida albicans. Informed that according to the International Date Base, US Census Bureau, the prevalence of the Indonesian population suffering from dandruff is 43,833,262 out of 238,452,952 people. Pineapple skin (Ananas comosus (L.) Merr) is a natural ingredient that contains compounds that have antifungal properties, such as flavonoids, alkaloids, tannins and bromelain enzymes. In addition, the enzyme content of bromelain found in pineapple peel (Ananas comosus (L.) Merr) also has anti-inflammatory, anti-cancer and antibacterial properties. This study aims to determine the antifungal activity of the ethanol extract of pineapple peel (Ananas comosus (L.) Merr) on the growth of Pityrosporum ovale and Candida albicans which causes dandruff. The antifungal activity test was carried out by the disc diffusion method using disc paper at five concentrations, namely 5\%, 10\%, 15\%, 2\% ketoconazole positive control and 10\% DMSO negative control, planted on Sabouraud Dextrose Agar (SDA) media and Potato Dextrose Agar media. (PDA), which had previously been implanted with the tested mushroom culture using the swab method, then incubated at $370 \mathrm{C}$ for 3-5 $\times 24$ hours. The results showed that of the three concentrations, namely $5 \%, 10 \%$ and $15 \%$ had an average inhibition zone diameter of $7.77 \mathrm{~mm}, 10.33 \mathrm{~mm}, 11.99 \mathrm{~mm}$, respectively, and 2\% ketoconazole positive control. by $23 \mathrm{~mm}$. Where, at each concentration there was a significant difference $(p<0.05)$. Whereas Candida albicans was $7.99 \mathrm{~mm}, 10.14 \mathrm{~mm}, 11.55 \mathrm{~mm}$ and a positive control for ketoconazole $2 \%$ was $23 \mathrm{~mm}$. Where, at each concentration there was a significant difference $(p<0.05)$. Based on the results of this study, it can be concluded that the ethanol extract of pineapple peel (Ananas comosus (L.) Merr) at a concentration of $5 \%, 10 \%$ and $15 \%$ has antifungal activity against the growth of Pityrosporum ovale and Candida albicans which causes dandruff.
\end{abstract}

Keywords : Pineapple skin (Ananas comosus (L.) Merr), Antifungi, Pityrosporum ovale, Candida albicans

\section{ABSTRAK}

Ketombe adalah kondisi kulit kepala yang biasanya ditandai dengan gatal dan pengelupasan pada kulit kepala, hal ini dapat disebabkan oleh jamur Pityrosporum ovale dan Candida albicans. Diinformasikan menurut International Date Base, US Sensus Bureau, prevalensi populasi masyarakat Indonesia yang menderita ketombe sebesar 43.833 .262 dari 238.452.952 jiwa. Kulit Nanas (Ananas comosus (L.) Merr) merupakan suatu bahan alam yang mengandung senyawa yang berkhasiat sebagai antijamur seperti flavonoid, alkaloid, tannin dan enzim bromelain. Selain itu, kandungan enzim bromelain yang terdapat pada kulit nanas (Ananas comosus (L.) Merr) juga berkhasiat sebagai antiinflamasi, antikanker dan antibakteri. Penelitian ini bertujuan untuk mengetahui aktivitas antifungi ekstrak etanol kulit nanas (Ananas comosus (L.) Merr) terhadap pertumbuhan Pityrosporum ovale dan Candida albicans penyebab ketombe. Uji aktivitas antifungi dilakukan dengan metode difusi cakram menggunakan kertas cakram terhadap lima konsentrasi yaitu 5\%, 10\%, 15\%, kontrol positif ketokonazol 2\% dan kontrol negatif DMSO 10\%, ditanam pada media Sabouraud Dextrose Agar (SDA) dan media Potato Dextrose Agar (PDA) yang sebelumnya telah ditanamkan biakan jamur uji dengan menggunakan metode swab kemudian diinkubasi pada temperatur $37^{\circ} \mathrm{C}$ selama $3-5 \times 24$ jam. Hasil penelitian menunjukkan bahwa dari tiga konsentrasi yaitu $5 \%, 10 \%$ dan $15 \%$ memiliki rata-rata diameter zona hambat berturut-turut terhadap Pityrosporum ovale sebesar $7,77 \mathrm{~mm}, 10,33 \mathrm{~mm}, 11,99 \mathrm{~mm}$ dan kontrol positif ketokonazol $2 \%$ sebesar $23 \mathrm{~mm}$. Dimana, pada setiap konsentrasi terdapat perbedaan bermakna $(\mathrm{p}<0,05)$. Sedangkan terhadap Candida albicans sebesar 7,99 mm, 10,14 $\mathrm{mm}, 11,55 \mathrm{~mm}$ dan kontrol positif ketokonazol $2 \%$ sebesar $23 \mathrm{~mm}$. Dimana, pada setiap konsentrasi terdapat perbedaan bermakna $(\mathrm{p}<0,05)$. Berdasarkan hasil penelitian ini, dapat disimpulkan bahwa ekstrak etanol kulit nanas (Ananas comosus (L.) Merr) pada konsentrasi 5\%, 10\% dan 15\% memiliki aktivitas antifungi terhadap pertumbuhan Pityrosporum ovale dan Candida albicans penyebab ketombe.

Kata kunci : Kulit Nanas (Ananas comosus (L.) Merr), Antifungi, Pityrosporum ovale, Candida albicans

\section{PENDAHULUAN}

Tingkat kepercayaan diri seseorang dapat menurun yang diakibatkan oleh salah satu gangguan pada rambut yang berketombe sehingga aktivitas kegiatan sehari-hari dapat terhambat. Ketombe merupakan salah satu gangguan atau kelainan pada kulit kepala yang ditandai dengan terkupasnya kulit mati disertai dengan pruritus hingga peradangan. Penyebab utama ketombe juga diakbiatkan karena sekresi kelenjar keringat yang berlebihan pada kulit, di samping itu adanya peranan mikroorganisme pada kulit kepala juga dapat memicu munculnya ketombe (Malonda et al., 2017). 
Salah satu mikroorganisme yang diduga dapat menyebabkan ketombe adalah Pityrosporum ovale. Jamur ini merupakan flora normal yang terdapat pada kulit kepala, namun jamur ini dapat tumbuh dengan subur pada kondisi rambut dengan kelenjar minyak berlebih. Selain itu, jamur Candida albicans juga merupakan salah satu penyebab timbulnya ketombe pada kulit kepala (Mahataranti et al., 2012; Malonda et al., 2017).

\section{Berdasarkan data dari beberapa} penelitian menunjukkan prevalensi penderita ketombe di dunia yaitu mencapai $50 \%$, dan menurut International Date Base, US Sensus Bureau, prevalensi populasi masyarakat Indonesia yang menderita ketombe sebesar 43.833.262 dari 238.452.952 jiwa. Hal ini menempati urutan ke empat setelah China, India dan Amerika Serikat. Di samping itu, prevalensi penderita ketombe pada laki-laki lebih besar daripada perempuan, karena tingginya hormon androgen pada laki-laki yang menyebabkan tingginya faktor resiko ketombe pada lakilaki (Malonda et al., 2017; Widowati et al., 2020).

Di Indonesia memiliki sumber daya alam yang melimpah, dan sala satu bahan alam yang memiliki potensi sebagai antiketombe yakni kulit nanas (Ananas comosus (L.) Merr). Kandungan kimia yang terdapat pada kulit nanas (Ananas comosus (L.) Merr) antara lain alkaloid, steroid, tannin dan flavonoid. Selain itu pada kulit nanas (Ananas comosus (L.) Merr) juga terdapat senyawa bromelain yang berpotensi sebagai antiinflamasi, antikanker, antibakteri dan antijamur yang bekerja dengan cara menstimulasi fagositosis serta menghambat semburan pernapasan dari Candida albicans ketika diinkubasi dengan tripsin secara in vitro (Damogalad et al., 2013; Juariah et al., 2018; Wiyati \& Tjitraresmi, 2018).

Berdasarkan informasi yang diberikan oleh masyarakat, secara empiris nanas dimanfaatkan sebagai obat penyembuh penyakit sembelit, mual-mual, gangguan saluran kemih, wasir, flu, kurang darah, serta berbagai penyakit kulit seperti gatal-gatal, eksim dan kudis (Rahmat et al., 2016).

Pada penelitian yang telah dilakukan oleh Juariah et al., (2018) menunjukkan adanya aktivitas antijamur terhadap pertumbuhan Trichophyton mentaghrophytes. Selain itu, penelitian lain yang telah dilakukan oleh Juariah et al, (2018) menunjukkan adanya aktivitas antijamur terhadap pertumbuhan Malassezia Furfur. Berdasarkan hal tersebut, dalam penelitian ini menguji aktivitas antifungi Ekstrak Etanol Kulit Nanas (Ananas comosus (L.) Merr) juga efektif dalam menghambat pertumbuhan Pityrosporum ovale dan Candida albicans penyebab ketombe.

\section{METODE}

\section{Desain, tempat dan waktu}

Desain penelitian yang digunakan adalah penelitian kuasi-eksperimental, dengan menggunakan metode difusi agar dengan teknik kertas cakram (paper disc). Penelitian ini dilaksanakan di Laboratoriun Mikrobiologi Farmasi, Fakultas Farmasi, Universitas Megarezky di Makassar.

\section{Bahan dan Alat}

Adapun bahan-bahan yang digunakan yaitu; aquadest steril, aluminium foil, benang godam, cotton swab, DMSO $10 \%$ (dimethyl sulfoxide), etanol $96 \%$, jamur uji Pityrosporum ovale dan Candida albicans, kulit Nanas (Ananas comosus (L.) Merr), kertas cakram (paper disc), kertas saring, kapas, ketokonazol $2 \%$, kertas perkamen, kertas HVS, medium Sabouraud Dextrose Agar (SDA), medium Potato Dextrose Agar (PDA) dan spoit $10 \mathrm{ml}$.

Adapun alat-alat yang digunakan yaitu; autoklaf, batang pengaduk, bunsen, blender, cawan petri, cawan porselen, erlenmeyer, fial, gelas ukur, gelas kimia, inkubator, jangka sorong, kain flannel putih, Laminar Air Flow (LAF), mortar, mangkok kaca, ose bulat, oven, water bath, pipet tetes, rotary evaporator, rak tabung reaksi, stamper, sendok tanduk, tabung reaksi, toples kaca, timbangan analitik, water bath dan kamera.

\section{Langkah- Langkah Penelitian Penyiapan Sampel}

Sampel kulit nanas (Ananas comosus (L.) Merr) yang telah diperoleh dikupas kemudian diambil kulitnya, dicuci dan dipotong-potong kecil, setelah itu dilakukan sortasi basah untuk menghilangkan kotoran pada sampel, selanjutnya diangin-anginkan sampai kering tanpa terkena sinar matahari langsung, kemudian dilakukan sortasi kering untuk memastikan sampel benar-benar bersih dari kotoran yang ikut pada saat proses 
pengeringan. Kemudian dihaluskan menggunakan blender hingga diperoleh serbuk simplisia yang halus.

\section{Pembuatan Ekstrak}

Ekstrak kulit nanas (Ananas comosus (L.) Merr) dibuat dengan proses maserasi. Serbuk simplisia dimasukkan ke dalam wadah gelas dan direndam dengan cairan penyari etanol $96 \%$ selama 7 hari dalam keadaan tertutup rapat, kemudian dibiarkan ditempat sejuk dan terlindung dari cahaya sambil sesekali diaduk. Filtrat yang dihasilkan disaring dan ampasnya direndam kembali dengan pelarut yang sama. Hal ini dilakukan sampai pelarut menjadi jernih. Kemudian diuapkan dengan menggunakan Rotary Evaporator hingga diperoleh ekstrak kental. Ekstrak kental yang diperoleh kemudian ditimbang dan dicampurkan dengan DMSO 10\% kemudian dibuat dalam konsentrasi $5 \%, 10 \%$, dan $15 \%$ (Yusuf \& Alyidrus, 2020; Yusuf \& Wati, 2019).

\section{Sterilisasi Alat}

Seluruh alat-alat yang digunakan dalam penelitian ini harus disterilisasi terlebih dahulu sebelum digunakan.

\section{Pembuatan Medium Agar Miring}

Ditimbang medium Potato Dextrose Agar (PDA) sebanyak 0,78 g kemudian dilarutkan dengan aquadest sebanyak $20 \mathrm{ml}$ menggunakan Erlenmeyer $(39 \mathrm{~g} / 1000 \mathrm{ml})$. Setelah itu dihomogenkan dengan batang pengaduk diatas penangas air hingga mendidih dan diperoleh larutan jernih. Diambil medium sebanyak $5 \mathrm{ml}$ dan dituang pada masing-masing tabung reaksi steril kemudian di tutup menggunakan aluminium foil. Media tersebut diterilkan dalam autoklaf pada suhu $121^{\circ} \mathrm{C}$ selama 15 menit, kemudian dibiarkan pada suhu ruang selama \pm 30 menit hingga media memadat pada kemiringan $30^{\circ}$. Media agar miring digunakan untuk inokulasi jamur.

\section{Peremajaan dan Inokulasi Jamur Uji Isolat jamur Pityrosporum ovale dan Candida albicans diambil dengan jarum ose steril kemudian ditanamkan pada media Potato Dextrose Agar (PDA) dengan cara menggores secara zig-zag di atas permukaan medium agar miring, mulai dari ujung bagian bawah sampai ujung bagian atas. Lalu diinkubasi pada temperatur $37^{\circ} \mathrm{C}$ selama 18-24 jam dan didapatkan koloni jamur.}

\section{Pembuatan Kontrol Positif Ketokonazol $2 \%$ \\ Ditimbang ketokonazol sebanyak 2 gram kemudian dilarutkan dengan aquadest steril sebanyak $8 \mathrm{ml}$ lalu dihomogenkan.}

\section{Pembuatan Kontrol Negatif DMSO 10\% \\ Untuk kontrol negatif terhadap jamur \\ Pityrosporum ovale dan Candida albicans digunakan DMSO 10\% dengan cara dipipet DMSO sebanyak $10 \mathrm{ml}$ dan dilarutkan dengan aquadest steril sebanyak $90 \mathrm{ml}$ kemudian dihomogenkan. \\ Pembuatan Media Saboraud Dextrose Agar (SDA) \\ Ditimbang Sabouraud Dextrose} Agar (SDA) sebanyak 3,25 gram kemudian dilarutkan dengan aquadest sampai $50 \mathrm{ml}$ (65 gram $/ 1000 \mathrm{ml}$ ). Suspensi yang dihasilkan kemudian dipanaskan hingga jernih, campuran tersebut di sterilisasi dalam autoklaf pada temperatur $121^{\circ} \mathrm{C}$ selama \pm 15 menit. Media dituang ke dalam setiap cawan petri steril masing-masing $10 \mathrm{ml}$ secara aseptik, lalu di diamkan hingga memadat.

\section{Pembuatan Media Potato Dextrose Agar (PDA)}

Ditimbang Potato Dextrose Agar (PDA) sebanyak 1,95 gram kemudian dilarutkan dengan aquadest sampai $50 \mathrm{ml}$ (39 gram/1000 ml). Suspensi yang dihasilkan kemudian dipanaskan hingga mendidih, campuran tersebut di sterilisasi dalam autoklaf pada temperatur $121^{\circ} \mathrm{C}$ selama \pm 15 menit. Media dituang ke dalam setiap cawan petri steril masing-masing 10 $\mathrm{ml}$ secara aseptik, lalu di diamkan hingga memadat.

\section{Pengujian Aktivitas Antijamur}

Diambil tabung reaksi dari autoklaf yang berisi media Saboraud Dextrose Agar (SDA) dan media Potato Dextrose Agar (PDA) sebanyak $10 \mathrm{ml}$. Kemudian dituang media pada masing-masing cawan petri steril, lalu didiamkan selama beberapa menit hingga media memadat. Setelah itu jamur uji diambil dengan menggunakan cotton swab lalu digoreskan di atas permukaan medium yang telah memadat secara merata. Kemudian dicelupkan kertas cakram (paper disc) pada masing-masing konsentrasi $(5 \%$, $10 \%$, dan $15 \%$ ), kontrol positif Ketokonazol $2 \%$ dan kontrol negatif DMSO 10\%, setelah itu diletakkan pada permukaan medium. 
Lalu diinkubasi selama 3-5 x 24 jam pada temperatur $37^{\circ} \mathrm{C}$. Setelah itu hasil dibaca dengan cara mengukur diameter zona hambat pada media uji menggunakan jangka sorong $(\mathrm{mm})$.

\section{Pengolahan dan analisis data}

Data yang dikumpulkan merupakan data primer yaitu dengan cara mengukur zona hambat yang terbentuk dengan menggunakan jangka sorong $(\mathrm{mm})$. Hasil pengukuran zona hambat yang diperoleh ditampilkan dalam bentuk tabel dan grafik. Data yang terkumpul kemudian diuji normalitas dengan menggunakan uji Shapiro Wilk, kemudian dilanjutkan dengan uji One Way Anova (Analysis of Variance).

\section{HASIL}

Berdasarkan hasil pengujian Laboratorium tentang uji aktivitas antifungi ekstrak etanol kulit nanas (Ananas comosus (L.) Merr) terhadap pertumbuhan Pityrosporum ovale dan Candida albicans penyebab ketombe menggunakan metode difusi agar dengan teknik kertas cakram (paper disc) dan konsentrasi ekstrak etanol kulit nanas (Ananas comosus (L.) Merr) yaitu $5 \%$, 10\% dan $15 \%$ diperoleh hasil sebagai berikut.

Hasil pengukuran diameter zona hambat ekstrak etanol kulit nanas (Ananas comosus (L.) Merr) terhadap pertumbuhan Pityrosporum ovale dapat dilihat pada tabel 1. Untuk kelompok 1 (ekstrak etanol kulit nanas $5 \%$ ) diperoleh mean \pm SD zona hambat sebesar 7,77 $\pm 0,50$ dengan kategori zona hambat yang sedang. Pada kelompok 2 (ekstrak etanol kulit nanas 10\%) diperlihatkan bahwa nilai mean $\pm S D$ zona hambat sebesar 10,33 $\pm 0,33$ yang termasuk kategori kuat. Pada kelompok 3 (ekstrak etanol kulit nanas $15 \%$ ) nilai mean \pm SD zona hambat sebesar 11,99 $\pm 0,66$ yang termasuk kategori kuat. Pada kelompok 4 (kontrol positif Ketokonazol 2\%) nilai mean \pm SD zona hambat sebesar $23,00 \pm 1,00$ yang termasuk kategori sangat kuat. Pada kelompok 5 (kontrol negatif DMSO 10\%) nilai mean \pm SD zona hambat sebesar $0,00 \pm 0,00$ yang menandakan tidak ada penghambatan.

Hasil pengukuran diameter zona hambat ekstrak etanol kulit nanas (Ananas comosus (L.) Merr) terhadap pertumbuhan Candida albicans dapat dilihat pada tabel 2. Untuk kelompok 1 ekstrak etanol kulit nanas $5 \%$ ) diperoleh mean \pm SD zona hambat sebesar 7,99 $\pm 0,66$ dengan kategori zona hambat yang sedang. Pada kelompok 2 (ekstrak etanol kulit nanas 10\%) diperlihatkan bahwa nilai mean $\pm S D$ zona hambat sebesar 10,14 $\pm 0,16$ termasuk kategori kuat. Pada kelompok 3 (ekstrak etanol kulit nanas $15 \%$ ) nilai mean \pm SD zona hambat sebesar 11,55 $\pm 0,50$ termasuk kategori kuat. Pada kelompok 4 (kontrol positif Ketokonazol 2\%) nilai mean \pm SD zona hambat sebesar 23,00 $\pm 1,00$ termasuk kategori sangat kuat. Pada kelompok 5 (kontrol negatif DMSO 10\%) nilai mean \pm SD zona hambat sebesar $0,00 \pm 0,00$ menandakan tidak ada penghambatan.

\section{PEMBAHASAN}

Penelitian tentang aktivitas antifungi dari ekstrak etanol kulit nanas (Ananas comosus (L.) Merr) terhadap pertumbuhan Pityrosporum ovale dan Candida albicans dilakukan dengan menggunakan metode difusi agar dengan teknik kertas cakram (paper disc) dengan tujuan untuk menentukan potensi aktivitas antifungi ekstrak etanol kulit nanas (Ananas comosus (L.) Merr) terhadap pertumbuhan Pityrosporum ovale dan Candida albicans penyebab ketombe. Pada penelitian ini, menggunakan medium Sabouraud Dextrose Agar (SDA) dan medium Potato Dextrose Agar (PDA) yang merupakan media pertumbuhan atau sumber nutrisi bagi pertumbuhan jamur uji (Malonda et al., 2017; Onggo, 2015).

Kontrol positif yang digunakan pada penelitian ini yaitu ketokonazol $2 \%$. Hal ini berdasarkan karena ketokonazol merupakan antijamur turunan imidazol yang berspektrum luas dan bersifat fungistatik, obat ini menghasilkan kadar plasma yang cukup untuk menekan aktivitas berbagai jenis jamur (Ganiswarna, 2016). Dari hasil yang didapatkan bahwa kontrol positif memiliki kategori zona hambat sangat kuat pada pertumbuhan jamur Pityrosporum ovale dan Candida albicans dibandingkan dengan ekstrak etanol kulit nanas (Ananas comosus (L.) Merr). Juariah et al., (2018) menyatakan bahwa ketokonazol sering digunakan sebagai antijamur, dimana mekanisme kerja dalam penghambatan pertumbuhan jamur dengan menghasilkan kadar plasma yang cukup untuk menekan aktivitas berbagai jenis jamur, melalui biosintesis ergosterol dalam sel jamur dengan menghambat enzim sitokrom P450 sehingga menyebabkan terganggunya sintesis ergosterol yang merupakan 
komponen penting dari membrane sel jamur.

DMSO10\% digunakan sebagai kontrol negatif karena untuk mengetahui pengaruh pelarut terhadap pertumbuhan jamur uji, sehingga dapat diketahui bahwa aktivitas yang ditunjukkan oleh ekstrak etanol kulit nanas (Ananas comosus (L.) Merr) adalah zat yang terkandung dalam sampel, bukan berasal dari pelarut yang digunakan, selain itu DMSO merupakan pelarut organik dan tidak bersifat bakterisidal, selain itu pelarut ini dapat melarutkan hampir semua senyawa polar maupun nonpolar (Assidqi et al., 2012; Basarang \& Rianto, 2018). Dari hasil pengujian DMSO $10 \%$ pada penelitian ini tidak menunjukkan adanya zona hambat yang dihasilkan pada pertumbuhan jamur Pityrosporum ovale dan Candida albicans dibandingkan dengan ekstrak etanol kulit nanas (Ananas comosus (L.) Merr) dan kontrol positif Ketokonazol 2\%.

Hasil pengujian zona hambat pada Pityrosporum ovale menunjukkan bahwa ekstrak etanol kulit nanas (Ananas comosus (L.) Merr) pada konsentrasi $5 \%$ memiliki kategori zona hambat sedang, konsentrasi $10 \%$ kategori zona hambat kuat, konsentrasi $15 \%$ kategori zona hambat kuat, kontrol positif ketokonazol kategori zona hambat sangat kuat dan kontrol negarif DMSO 10\% tidak menunjukkan adanya daya hambat terhadap pertumbuhan Pityrosporum ovale. Pada pengujian ini menunjukkan zona hambat paling besar ditunjukkan oleh ekstrak kulit nanas pada konsentrasi $15 \%$. Selanjutnya, pada hasil pengukuran zona hambat pada Candida albicans menunjukkan bahwa ekstrak etanol kulit nanas (Ananas comosus (L.) Merr) pada konsentrasi $5 \%$ memiliki kategori zona hambat sedang, konsentrasi $10 \%$ kategori zona hambat kuat, konsentrasi $15 \%$ kategori zona hambat kuat, kontrol positif ketokonazol kategori zona hambat sangat kuat dan kontrol negarif DMSO 10\% tidak menunjukkan adanya daya hambat terhadap pertumbuhan Candida albicans. Pada pengujian ini juga menunjukkan zona hambat paling besar ditunjukkan oleh ekstrak kulit nanas pada konsentrasi $15 \%$.

Pada hasil statistik menggunakan uji normalitas Shapiro Wilk data hasil pengukuran zona hambat pada Pityrosporum ovale dan Candida albicans dari ketiga replikasi pada konsentrasi ekstrak kulit nanas (Ananas comosus (L.)
Merr) $5 \%, 10 \%$, dan $15 \%$ data dinyatakan terdistribusi normal karena memperoleh nilai signifikan >0.05. Selanjutnya, hasil uji statistik One Way Anova pada Pityrosporum ovale yang telah dilakukan diperoleh nilai signifikan sebesar 0.000 dan pada Candida albicans diperoleh nilai signifikan Sebesar 0.000 menunjukkan terdapat perbedaan nilai rata-rata secara signifikan dari data tersebut. Selanjutnya dilakukan uji lanjutan menggunakan metode Tukey untuk melihat perbedaan rata-rata dari tiap kelompok. Dimana, pada uji pos hoc test pada Pityrosporum ovale dan Candida albicans antara konsentrasi $5 \%, 10 \%$, dan $15 \%$ diperoleh nilai signifikan $\mathrm{p}<0,05$ menunjukkan bahwa terdapat perbedaan rata-rata diameter zona hambat pada masing-masing konsentrasi. Hal ini juga sesuai dengan yang dinyatakan oleh Juariah et al. (2018) bahwa hasil dari pengujian menunjukkan ekstrak kulit nanas dapat menghambat pertumbuhan jamur, semakin besar konsentrasi ekstrak maka semakin besar potensi aktivitasnya.

Potensi antifungi dari kulit nanas disebabkan adanya senyawa aktif yang terdapat dalam ekstrak etanol kulit nanas (Ananas comosus (L.) Merr) salah satunya yaitu Bromelin. Bromelin memiliki kemampuan aktivitas anti jamur (Wiyati \& Tjitraresmi, 2018). Selain itu Damogalad et al. (2013) menyatakan bahwa flavanoid pada kulit nanas berperan sebagai antioksidan yang potensial dalam melindungi kulit dari berbagai pertumbuhan jamur.

\section{KESIMPULAN}

Penelitian ini dapat disimpulkan bahwa ekstrak etanol kulit nanas (Ananas comosus (L.) Merr) memiliki aktivitas antifungi terhadap pertumbuhan Pityrosporum ovale dan Candida albicans penyebab ketombe.

Ekstrak etanol kulit nanas (Ananas comosus (L.) Merr) pada konsentrasi 5\%, $10 \%$ dan $15 \%$ memiliki aktivitas antijamur terhadap Pityrosporum ovale dan Candida albicans.

Ekstrak etanol kulit nanas (Ananas comosus (L.) Merr) dengan konsentrasi 15\% mempunyai aktivitas antifungi paling baik dibandingkan konsentrasi $5 \%$ dan $10 \%$.

\section{SARAN}

Diharapkan kepada penelitian
selanjutnya untuk mengembangkan 
penelitian ini dengan pengujian ekstrak etanol kulit nanas (Ananas comosus (L.) Merr) terhadap mikroorganisme jenis lain dan dengan konsentrasi yang berbeda maupun metode yang lainnya. Dengan dilaksanakannya penelitian ini diharapkan kepada masyarakat agar dapat lebih memanfaatkan kulit nanas (Ananas comosus (L.) Merr) sebagai pengobatan tradisional dibandingkan penggunaan obatobat sintetis yang dapat mengakibatkan efek samping.

\section{DAFTAR PUSTAKA}

Assidqi, K., Tjahjaningsih, W., \& Sigit, S. (2012). Potensi ekstrak daun patikan kebo (Euphorbia hirta) Sebagai Antibakteri Terhadap Aeromonas hydrophila Secara In Vitro. 1(2), 113124.

Basarang, M., \& Rianto, R. (2018). Pertumbuhan Candida sp dan Aspergillus $\mathrm{sp}$ dari Bilasan Bronkus Penderita Tuberkulosis Paru pada Media Bekatul Growth of Candida sp and Aspergillus sp from Bronchoscopy Pulmonary Tuberculosis Patients on Bran Media. IImu Alam Dan Lingkungan, 9(18), 80.

Damogalad, V., Jaya Edy, H., \& Sri Supriati, H. (2013). Formulasi Krim Tabir Surya Ekstrak Kulit Nanas (Ananas Comosus L Merr) Dan Uji in Vitro Nilai Sun Protecting Factor (Spf). PHARMACON Jurnal IImiah Farmasi - UNSRAT, 2(02), 2302-2493. https://ejournal. unsrat.ac.id/index.php/pharmacon/arti cle/view/1577/1269

Ganiswarna, S. G. (2016). Farmakologi Dan Terapi Edisi 6. In Departeman Farmakologi dan Terapeutik FKUI.

Juariah, S., Pratiwi Irawan, M., \& Yuliana, Y. (2018). EFEKTIFITAS EKSTRAK ETANOL KULIT NANAS (Ananas Comosus L. Merr) terhadap Trichophyton mentaghrophytes. JOPS (Journal Of Pharmacy and Science), 1(2), 1-9. https://doi.org/10.36341/ jops.v1i2.486

Mahataranti, N., Astuti, I. Y., \& Asriningdhiani, B. (2012). Formulasi Shampo Antiketombe Ekstrak Etanol Seledri (Apium graveolens L). Pharmacon-Jurnal Ilmiah Farmasi,
09(02), 128-138. http://jurnalnasional.ump.ac.id/index.p hp/PHARMACY/article/view/710

Malonda, T. C., Yamlean, P. V. Y., \& Citraningtyas, G. (2017). Formulasi Sediaan Sampo Antiketombe Ekstrak Daun Pacar Air ( Impatiens balsamina L .) Dan Uji Aktivitasnya Terhadap Jamur Candida albicans ATCC 10231 Secara In Vitro. PHARMACON Jurnal Ilmiah Farmasi, 6(4). https://ejournal.unsrat.ac.id/index.php/ pharmacon/article/view/17725/17250

Rahmat, D., L, D. R., Nurhidayati, L., \& Bathini, M. A. (2016). Peningkatan Aktivitas Antimikroba Ekstrak Nanas (Ananas comosus (L.) Merr) Dengan Pembentukan Nanopartikel. Jurnal Sains Dan Kesehatan, 1(5). https://jsk.farmasi.unmul.ac.id/index.p hp/jsk/article/view/45/40

Widowati, P. D., Zalfani, Q. R., Lestari, A. V., Syahbana, S. N., Putri, N. R. A., Sena, R. Y., Wulandari, D. A. B., Prabansari, A. K., Fajrin, N. G., \& Sukorini, A. I. (2020). Identifikasi Pengetahuan Dan Penggunaan Produk Antiketombe Pada Mahasiswa Upn Veteran Surabaya. Jurnal Farmasi Komunitas, $7(1), \quad 31$. https://doi.org/10.20473/ jfk.v7i1.21661

Wiyati, P. I., \& Tjitraresmi, A. (2018). Karakterisasi, Aktivasi, dan Isolasi Enzim Bromelin dari Tumbuhan Nanas (Ananas sp.). Farmaka, 16(2), 179185. JF.V16I2.17521.G8754

Yusuf, M., \& Alyidrus, R. (2020). Uji Antiangiogenesis Secara In Vivo Ekstrak Etanol Biji Kopi Robusta (Coffea Robusta) dengan Metode Chorio Allantoic Membrane (CAM). Jurnal Farmasi Galenika (Galenika Journal of Pharmacy) (e-Journal), 6(1), 63-69. https://doi.org/10.22487/ j24428744.2020.v6.i1.14975

Yusuf, M., \& Wati, A. (2019). Efek Infus Kayu Secang (Caesalpinia sappan L.) Terhadap Penurunan Kadar Gula Darah Mencit (Mus musculus). Media Farmasi Poltekkes Makassar, XV(1), 1-8. 
Tabel 1.

Hasil pengukuran diameter Zona Hambat ekstrak etanol kulit nanas (Ananas comosus (L.)

\begin{tabular}{cccc}
\hline $\begin{array}{c}\text { Kelompok } \\
\text { Perlakuan }\end{array}$ & $\mathbf{n}$ & $\begin{array}{c}\text { Zona Hambat }(\mathbf{m m}) \\
\text { Mean } \pm \text { SD }\end{array}$ & Kategori Zona Hambat \\
\hline K1 & 3 & $7,77 \pm 0,50$ & Sedang \\
K2 & 3 & $10,33 \pm 0,33$ & Kuat \\
K3 & 3 & $11,99 \pm 0,66$ & Kuat \\
K4 & 3 & $23,00 \pm 1.000$ & Sangat kuat \\
K5 & 3 & $0,00 \pm 0,00$ & Tidak menghambat \\
\hline
\end{tabular}

\section{Keterangan:}

- $\mathrm{K} 1=$ Konsentrasi ekstrak kulit nanas $5 \%$

- $\mathrm{K} 2$ = Konsentrasi ekstrak kulit nanas $10 \%$

- $\quad \mathrm{K} 3=$ Konsentrasi ekstrak kulit nanas 15\%

- $\mathrm{K} 4$ = Kontrol positif (Ketokonazol 2\%)

- $\quad \mathrm{K} 5=$ Kontrol negatif (DMSO 10\%)

- $\quad \mathrm{n}=$ Jumlah replikasi

- Mean = Nilai rata-rata zona hambat

- $\mathrm{SD}=$ Standar deviasi

Tabel 2.

Hasil pengukuran diameter Zona Hambat ekstrak etanol kulit nanas (Ananas comosus (L.) Merr) terhadap pertumbuhan Candida albicans

\begin{tabular}{cccc}
\hline $\begin{array}{c}\text { Kelompok } \\
\text { Perlakuan }\end{array}$ & $\mathbf{n}$ & $\begin{array}{c}\text { Zona Hambat }(\mathbf{m m}) \\
\text { Mean } \pm \text { SD }\end{array}$ & Kategori Zona Hambat \\
\hline K1 & 3 & $7,99 \pm 0,66$ & Sedang \\
K2 & 3 & $10,14 \pm 0,16$ & Kuat \\
K3 & 3 & $11,55 \pm 0,50$ & Kuat \\
K4 & 3 & $23,00 \pm 1.000$ & Sangat kuat \\
K5 & 3 & $0,00 \pm 0,00$ & Tidak menghambat \\
\hline
\end{tabular}

Keterangan:

- $\mathrm{K} 1=$ Konsentrasi ekstrak kulit nanas $5 \%$

- $\quad \mathrm{K} 2=$ Konsentrasi ekstrak kulit nanas 10\%

- $\mathrm{K} 3=$ Konsentrasi ekstrak kulit nanas 15\%

- $\quad \mathrm{K} 4$ = Kontrol positif (Ketokonazol 2\%)

- $\quad$ K5 = Kontrol negatif (DMSO 10\%)

- $\quad \mathrm{n}=$ Jumlah replikasi

- Mean = Nilai rata-rata zona hambat

- SD = Standar deviasi

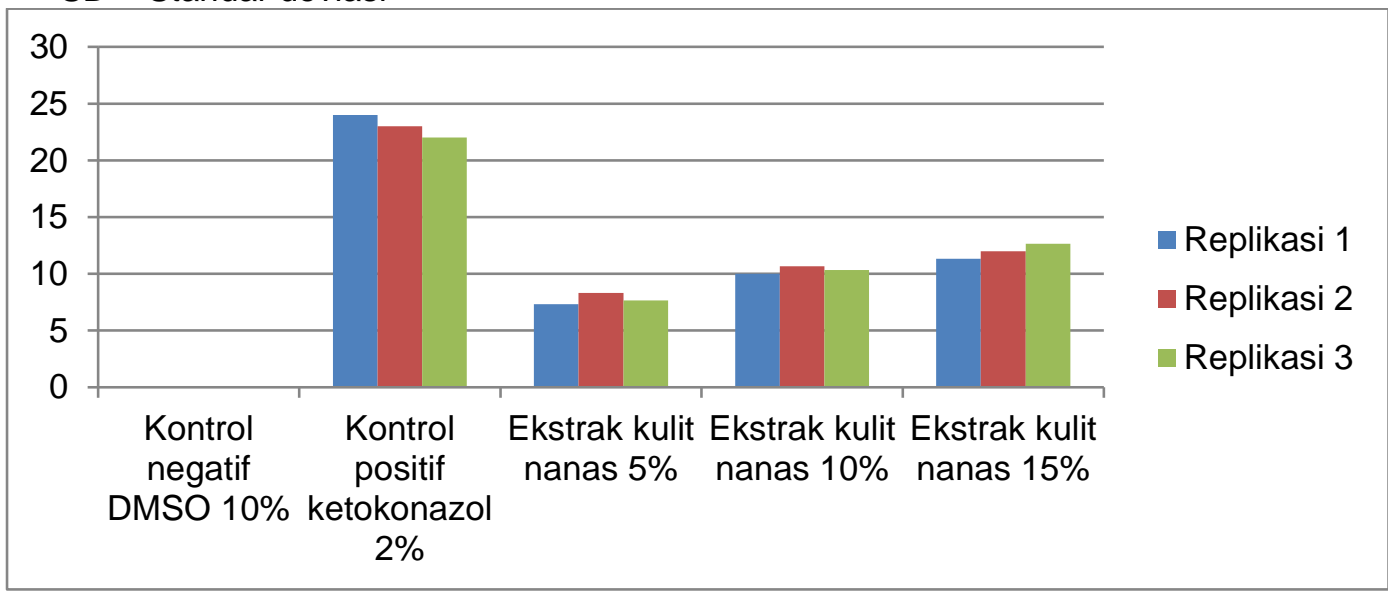

Gambar 1. Diagram hasil pengukuran zona hambat Pityrosporum ovale 


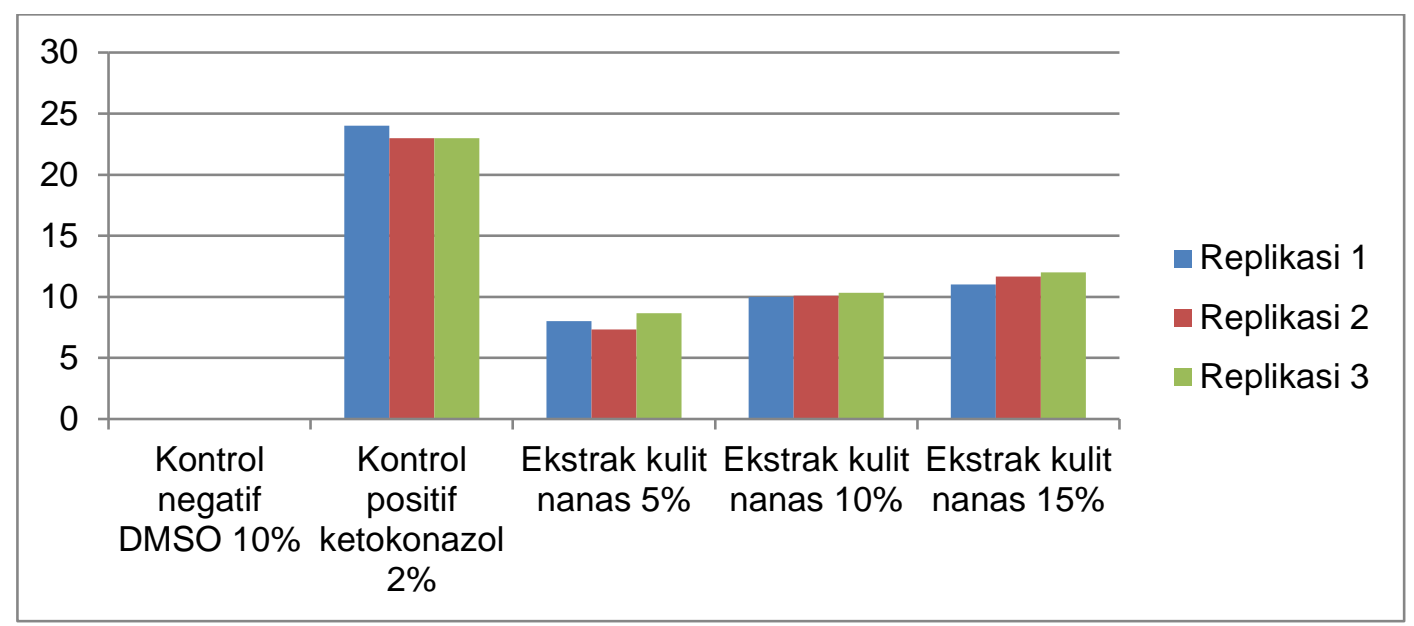

Gambar 2. Diagram hasil pengukuran zona hambat Candida albicans 